\title{
低エネルギーレーザーの疼痛緩和のメカニズム
}

\author{
齋 藤勇茂呂祐利子*中川敏 浩* \\ 奥羽大学歯学部口腔機能分子生物学講座生物学分野 \\ *奥羽大学歯学部生体構造学講座口腔組織学分野
}

(受付 : 2010 年 8 月 27 日, 受理 : 2010 年 10 月 16 日)

\section{Mechanisms of the Analgesic Effect of Low Energy Laser}

\author{
Isamu SAITO, Yuriko MORO* and Toshihiro NAKAGAWA* \\ Division of Biology, Department of Oral Function and Molecular Biology, \\ Ohu University School of Dentistry \\ *Division of Oral Histology, Department of Morphological Biology, \\ Ohu University School of Dentistry
}

(Received: August 27, 2010, Accepted for Publication: October 16, 2010)

\begin{abstract}
Low energy lasers are widely used in the treatment of various chronic pain syndromes in dentistry, pain clinics and orthopedics. It is generally agreed that low energy laser irradiation is effective for improving blood circulation, reducing pain and promoting wound healing. Although there have been many fundamental studies on the effects of lasers, the mechanism of laser-induced analgesic effects remains unknown. This report describes the effects of low energy laser irradiation on nerve cells in vitro, and demonstrates the mechanism of analgesic effect. A GaAlAs diode laser (trinpl D, YOSHIDA) and the neurosecretory PC12 cell line were used. After short-term laser irradiation $\left(0.3-0.5 \mathrm{~J} / \mathrm{cm}^{2}\right)$ on PC12 cells differentiated by treatment with nerve growth factor, terminals of neurites swelled within a few minutes and the number of synaptic vesicles decreased. After long-term laser irradiation $\left(15.0 \mathrm{~J} / \mathrm{cm}^{2}\right)$, synaptic vesicles completely disappeared from the swollen terminals, whereas cell bodies were still well preserved. Some of the cells appeared to be in degeneration and retracted their neurites accompanied with the alteration of F-Actin structures. The laser irradiation induced a temporary increase in intracellular free calcium ion concentration $\left(\left[\mathrm{Ca}^{2+}\right] \mathrm{i}\right)$ and enhanced the amplitude of calcium oscillation.

Thus, it is clearly demonstrated that the mechanism of laser-induced analgesic effects is that the laser stimulates calcium ion influx and neurotransmitter release, and then degenerates the terminals and processes of neurites, according to the alteration of F-Actin organization. These findings suggest that low energy laser attenuates the sensitivity of nerve cells to painful stimuli and produces analgesic effects.
\end{abstract}

(J. Jpn. Soc. Laser Dent. $21: 157 \sim$ 160, 2010 Reprint requests to Dr. SAITO)

Key words = Low energy laser, Analgesic effect, Mechanism

キーワード=低エネルギーレーザー, 疼痛緩和, 作用機序

\section{緒言}

低エネルギーレーザーによる疼痛緩和作用に関しては, 1980 年 $P \log$ の報告 ${ }^{1)}$ 以来, さまざまな症例において痛み の症状が緩和されるとして, 臨床の現場でレーザーが頻用 されるようになってきた。しかし基礎的研究では, レー ザー照射により神経の興奮伝導が抑制されたとする報 告 ${ }^{2,3)}$ がある一方で, 電気生理学的にはまったく変化が認
められなかったとする報告 ${ }^{4,5)}$ もあり，レーザーによる疼 痛緩和作用及びその作用機序については, 未だ統一した見 解が得られていない。

われわれは長年にわたり, 各種培養細胞に及ぼす低エネ ルギーレーザーの生物学的作用に関する研究6) を行って きた。その中で, 神経の実験モデルとして神経細胞株 $\mathrm{PC} 12$ (以下 $\mathrm{PC} 12$ 細胞）と半導体レーザー（トリンプル

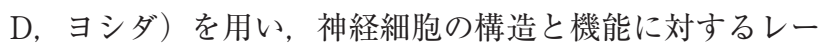



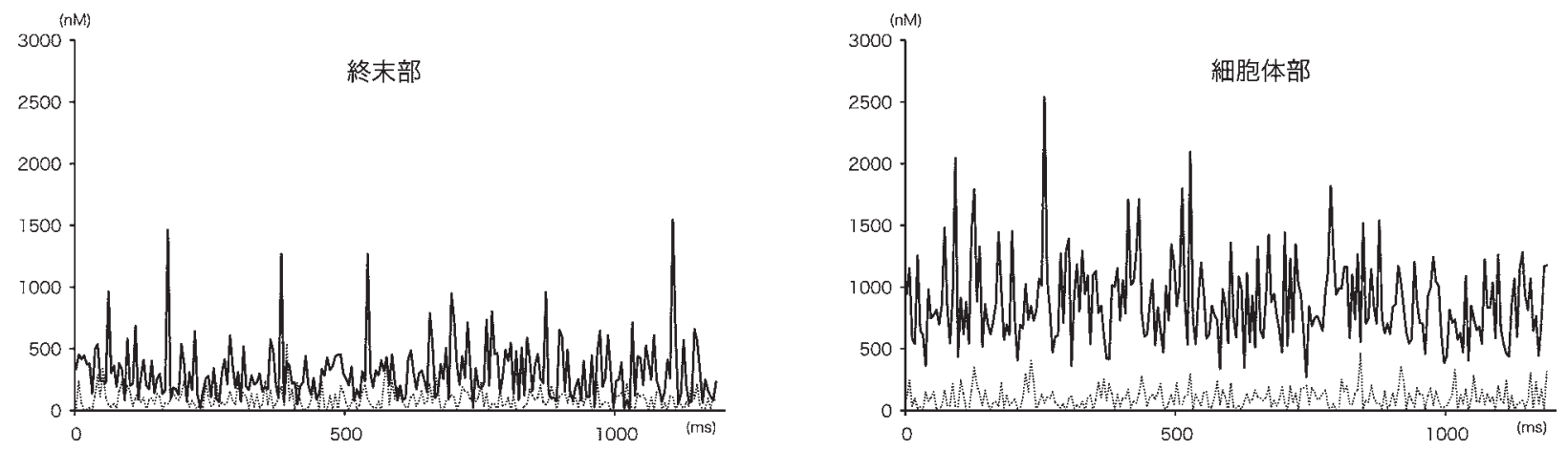

図 $1 \mathrm{PC} 12$ 細胞内フリーカルシウムイオン濃度の変動

非照射時 (破線) と比較して，レーザー照射後 (実線) は $\mathrm{Ca}^{2+}$ 濃度が著しく上昇し，振幅の大きな規則的変動を示す。 縦軸： $\mathrm{Ca}^{2+}$ 濃度 $(\mathrm{nM})$, 横軸：時間 $(\mathrm{ms})$

ザーの影響について調べた結果 ${ }^{7,8)}$, レーザーが PC12 細 胞に直接作用し, シナプスの構造変化と機能異常を引き起 こすという知見を得るに至った。

本稿では, 研究成果の概要とそこから導き出された疼痛 緩和のメカニズムについて論じ，レーザー治療に扔ける科 学的根拠の解明に供したい。

\section{疼痛システム}

痛みの伝達機構である疼痛システムは, 侵害性刺激を末 梢から中枢に伝導する痛覚伝導系と, 下行性に神経興奮を 制御する疼痛抑制系の 2 つの経路から成る。末梢神経線維 の侵害受容器に刺激が加わると一次ニューロンが興奮し, 上行性に神経線維を伝わり, 脊髄後角部で化学シナプスを 介して二次ニューロンに伝達される。信号はさらに視床か ら大脳に投射され，さまざまな情報をもとに“痛み”とし て解釈（認知）される。一方, 疼痛抑制系の中枢が下位脳 幹に存在し, 下行性に信号が脊䯣後角部に入力し, 一次 ニューロンの興奮を制御している（ゲートコントロール 説) ${ }^{9)}$ 。

この疼痛システムで最も重要な役割を担っているのが, 神経節内に存在する神経細胞体と, そこから長く伸びた神 経突起の先端に形成され, 神経間の情報伝達を行うシナプ ス構造である。

\section{神経細胞に及ぼすレーザーの影響}

\section{1. 微細構造の変化}

$\mathrm{PC} 12$ 細胞は, 神経成長因子 NGF を添加して培養する と, 長い神経突起とその先端にシナプス類似の終末部を形 成し，形態的にも機能的にも高度に分化した神経細胞と同 等の細胞に変化する。また，神経刺激を加えると， $\mathrm{Ca}^{2+}$ チャネルが開いて外部から $\mathrm{Ca}^{2+}$ が流入し，それにより神 経顆粒に含まれるドーパミン等の化学物質を開口分泌す る $^{10,11)}$ 。
PC12 細胞に半導体レーザーを短時間照射（40～60 秒, $\left.0.3 \sim 0.5 \mathrm{~J} / \mathrm{cm}^{2}\right)$ し, 電子顕微鏡で微細構造を調べてみる と, 照射直後に一部の神経突起終末部が腫大し, 神経顆粒 の数は減少する傾向にあった。レーザーを長時間照射（90 秒 $\times 20$ 回, $\left.15.0 \mathrm{~J} / \mathrm{cm}^{2}\right)$ すると, 大部分の終末部が著しく 腫大し，神経顆粒をすべて放出・消失した像が観察される ようになった。すなわち，レーザー刺激により神経伝達物 質が放出されるという現象を捉えることができた。

2. 細胞内フリーカルシウムイオン濃度の変動

細胞内フリーカルシウムイオン濃度 (以下 $\left[\mathrm{Ca}^{2+}\right] \mathrm{i}$ ) は, $\mathrm{Ca}^{2+}$ 動員機構と排出機構によって厳密に制御されている。 動員機構には, 細胞外からの $\mathrm{Ca}^{2+}$ 流入と細胞内貯蔵部位 （小胞体など）からの $\mathrm{Ca}^{2+}$ 放出があり，さまざまの刺激に よって細胞固有の規則的変動（カルシウムオシレーショ ン）を示すことが知られている ${ }^{12,13)}$ 。

$\mathrm{PC} 12$ 細胞の $\left[\mathrm{Ca}^{2+}\right] \mathrm{i}$ を調べてみると，レーザー照射直 後に $\left[\mathrm{Ca}^{2+}\right] \mathrm{i}$ が急激に増加するとともに，振幅が非常に 大きな規則的変動を示すこと，数分以内には照射前の状態 に戻ることなどが明らかになった。 $\mathrm{Ca}^{2+}$ 濃度 (nM) は, 非照射時には終末部で平均 $93 \mathrm{nM}$ (最大 $533 \mathrm{nM}$ ), 細胞体 部では平均 $103 \mathrm{nM}$ （最大 $459 \mathrm{nM}$ ）であったが, レーザー 照射後, 終末部では平均 $264 n M$ （最大 $1440 n M ）$, 細胞体

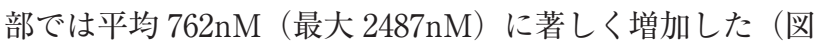
1)。

$\left[\mathrm{Ca}^{2+}\right] \mathrm{i}$ の増加現象は, 培地中の $\mathrm{Ca}^{2+}$ の有無に関わらず 観察することができた。このためレーザーは，細胞外から の $\mathrm{Ca}^{2+}$ 流入のみならず, 細胞内貯蔵部位 (小胞体) から の $\mathrm{Ca}^{2+}$ 放出も促していることが示唆される。土肥 ${ }^{14)}$ は, 培養上皮細胞を用いて $\mathrm{Ca}^{2+}$ チャネルのブロック実験を行 い, レーザーによる $\left[\mathrm{Ca}^{2+}\right] \mathrm{i}$ の上昇は, はじめに小胞体 膜の $\mathrm{Ca}^{2+}$ チャネルが開いて $\mathrm{Ca}^{2+}$ が放出され，その刺激で 細胞膜の $\mathrm{Ca}^{2+}$ チャネルが開き, 外部から多量の $\mathrm{Ca}^{2+}$ が流 入することによって生じると結論づけている。 

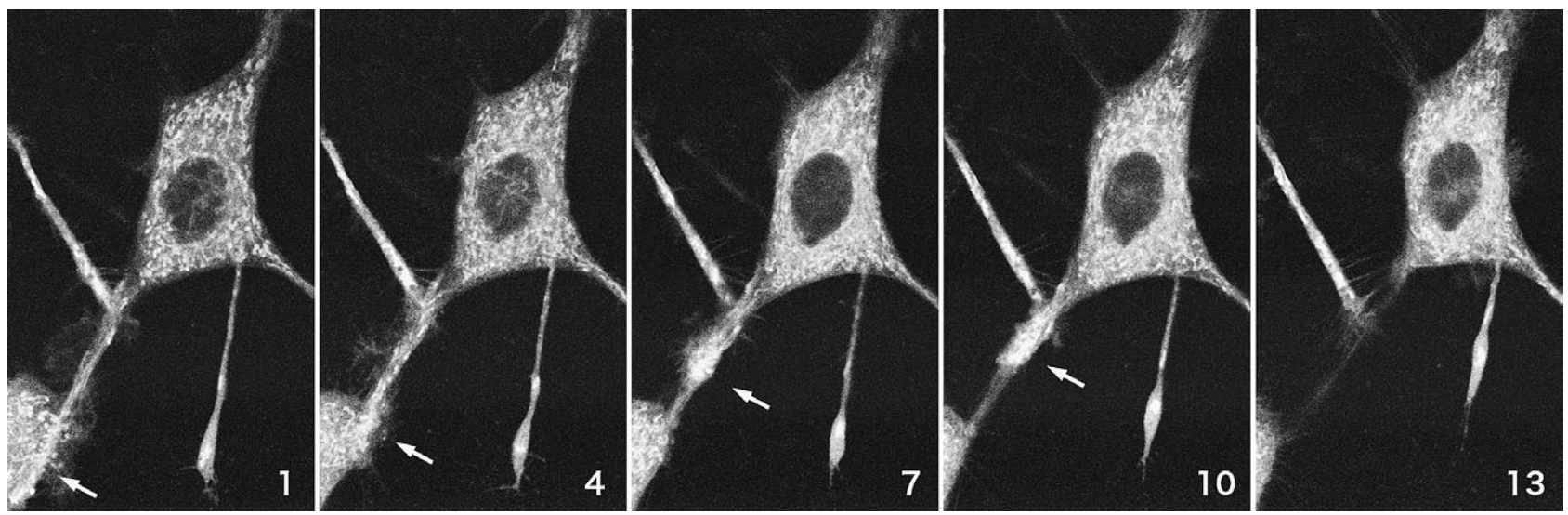

図 2 レーザー照射による神経突起の退縮（共焦点レーザー走査顕微鏡像）

レーザー 60 秒照射後, 白矢印の太い神経突起が徐々に短くなり，13 分後には細胞体内部に引き込まれる。右下に伸びる細い神経 突起も短くなる。数字はレーザー照射後の時間（分）を表す。

\section{3. 神経突起の退縮}

PC12 細胞にレーザー照射後, 同一細胞を顕微鏡下で経 時的に観察していると, 長く伸展していた神経突起が次第 に短くなり, 細胞体内部に吸収されてしまう像に遭遇する ことが頻繁にあった（図 2)。そこで, 細胞骨格を形成す るF-Actinについて検索したところ, レーザー照射後, 終 末部の腫大や崩壊に伴い F-Actin が凝集し, 塊状となるこ とが判明した。また, 神経突起部の F-Actin は細くなり断 裂した部分も認められたことから，これらが神経突起の退 縮を招く一要因と考えられる。因みに, PC12 細胞は神経 突起を失った場合でも，細胞自体への致死的ダメージとは ならずに, 神経突起は再構築される。

以上のごとく, PC12 細胞に低エネルギーレーザーを照 射すると, (1)細胞内シグナル伝達系の二次メッセンジャー として重要な役割を担う $\mathrm{Ca}^{2+}$ の濃度が一過性に上昇し, 特異なカルシウムオシレーションを生じること。(2)神経突 起の終末部においては神経顆粒が消失し, 終末部が著しく 腫大すること。さらには, (3) F-Actin の構造変化を伴い, 神経突起が変性退縮する場合もあることなど, レーザー照 射が神経細胞の微細構造変化及び機能異常を引き起こす実 態が明らかにされた。

\section{疼痛緩和のメカニズム}

低エネルギーレーザーによる疼痛緩和作用が, 生体内に おいてどのようにして得られるかについては種々の見解が 提唱されている ${ }^{15-17)}$ 。いわく，レーザーが血管を支配する 交感神経に働いて患部の血流改善を引き起こし, 発痛物質 が除去される。炎症症状の消退とともに発痛物質の産生が 抑制される。知覚神経が脱分極を起こし, 興奮伝導が遮断 される。経穴に照射すると下行性疼痛抑制系が賦活されて 痛覚閾值が上昇するなど, さまざまな要因が考えられ, そ

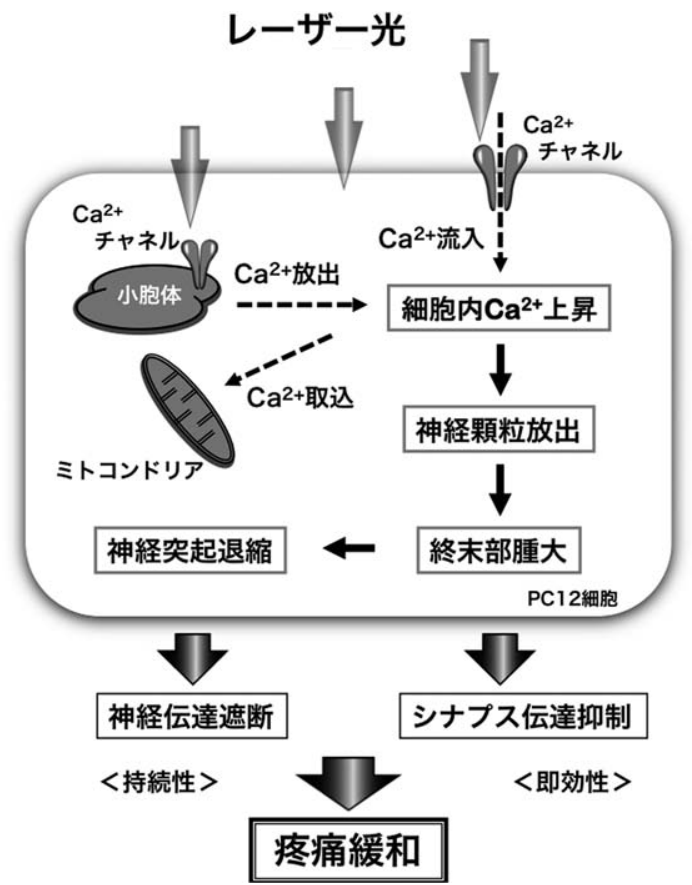

図 3 レーザー光による疼痛緩和のメカニズム レーザー光は神経細胞の $\mathrm{Ca}^{2+}$ チャネルに作用し， 細胞内の $\mathrm{Ca}^{2+}$ 濃度を一過性に上昇させる。これに より神経顆粒の放出, 終末部の腫大及び神経突起 の退縮が起こり，神経細胞の伝達機能が低下する ために疼痛緩和の効果が得られる。

の証明も試みられているが未だ定説は得られていない。 われわれは, PC12 細胞に及ぼすレーザー照射の影響に ついて検索した結果から, 疼痛緩和のメカニズムについて は次のように推察している（図 3)。

低エネルギーレーザーの光化学反応 (photo-chemical reaction）により, 細胞膜及び小胞体の $\mathrm{Ca}^{2+}$ チャネルが開 


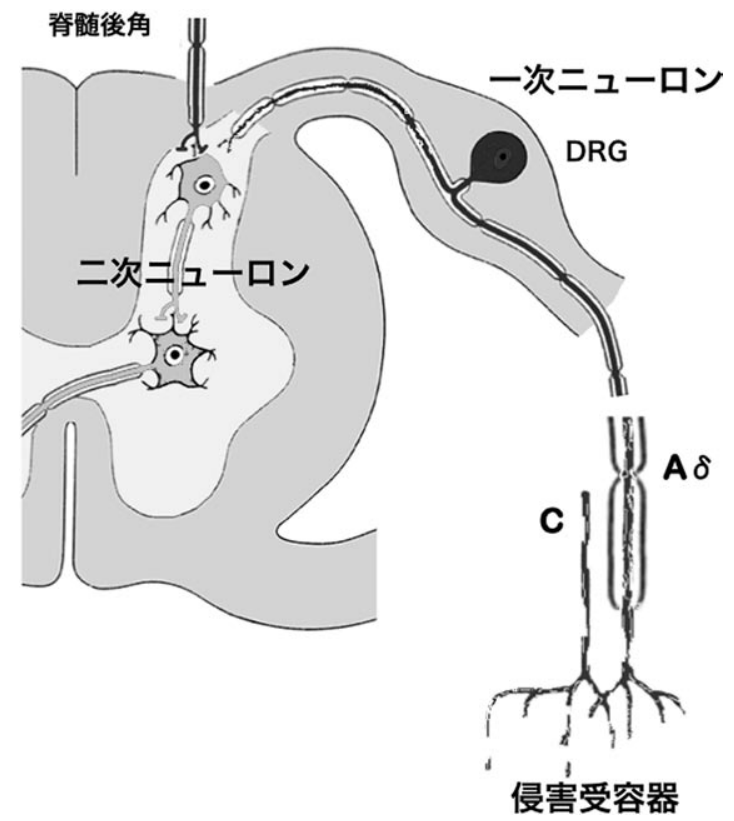

図 4 疼痛システムにおけるレーザーの作用 レーザーは末梢の侵害受容器 ( $\mathrm{A} \delta, \mathrm{C}$ 線維), 後根 神経節（DRG）の神経細胞体，脊髄後角部の二次 ニューロンとのシナプスに作用する。

き, 細胞外から多量の $\mathrm{Ca}^{2+}$ が流入し, 神経伝達物質の放 出が促される。さらに, 膜リサイクルの遅延などにより終 末部が腫大し, シナプス伝達が抑制される。これにより神 経細胞の刺激に対する反応性が一時的に低下し, 疼痛緩和 の即時的な効果が得られる。神経細胞の突起が変性・退縮 などの器質的変化を起こした場合は, 神経突起が再構築さ れるまで疼痛緩和の効果が長期間持続する。

このようにレーザーの疼痛緩和作用は, 局所の血流改善 や疼痛抑制系の賦活といった間接的要因よりもむしろ, レーザーが直接的に神経細胞に作用して生じる“伝達機能 の低下”が原因であり，その主たる機序は，レーザー光の 刺激により神経細胞の $\mathrm{Ca}^{2+}$ チャネルが開放されることに 起因するものと考える。

\section{おわりに}

生体内における疼痛システムの経路を考慮すると（図 4)，患部に照射されたレーザーは侵害受容器を介して，(1) 後根神経節 (DRG) に存在する神経細胞の $\mathrm{Ca}^{2+}$ 代謝異常 を引き起こす。(2)脊髄後角部において神経伝達物質の全放
出及び枯渇を引き起こし, 二次ニューロンへのシナプス伝 達を抑制する。(3)末梢にある侵害受容器の線維に変性・退 縮を引き起こし，興奮伝導を遮断する。

これらの作用により上行性の痛覚伝導経路が抑制あるい は遮断され, 痛み刺激が中枢に伝達され難くなるため, 疼 痛緩和の効果が得られるものと結論する。

\section{文献}

1) Plog FMW: Biological application of the laser beam. In: Koebner HK (ed): Laser in Medicine, New York-BrisbaneToront, 1980, John Wileys \& Sons Chichester, 21-37.

2）河谷正仁, 土屋喜由：低出力レーザーによる末梢感覚神経伝 導の遮断. ペインクリニック, $16: 533-539,1995$.

3）目澤修二：低出力レーザーの鎮痛効果及び骨組織形成促進効 果に関する研究. 日レ医誌, $17 ： 43-50,1996$.

4) Lundeberg T, Zhou J: Low power laser irradiation does not affect the generation of signals in a sensory receptor. Am J Chin Med, $16: 87-91,1988$.

5) Jarvis D, Maclver B, Tanelian DL: Electro-physiologic recording and thermodynamic modeling demonstrate that helium-neon laser irradiation does not affect peripheral $\mathrm{A} \delta$ - or C- fiber nociceptors. Pain, $43: 235-242,1990$.

6) 山本茂久, 齋藤 勇, 中川敏浩：培養細胞に及ぼすソフト レーザーの生物学的作用. 口脉組織培養学会誌, 8:1-11, 1999.

7）齋藤 勇：神経細胞株 PC12 に対する低出力レーザーの影響. 奥羽大歯学誌, $26 ： 67-88,1999$.

8）齋藤 勇, 土肥宏樹, 山本茂久：低レベルレーザーによる疼 痛緩和のメカニズム。 日レ歯誌, $13: 53-61,2002$.

9) Wall PD: The gate control theory of pain mechanisms. A re-examination and re-statement. Brain, $101: 1-18,1978$.

10) Greene LA, Tischler AS: Establishment of a nor-adrenergic clonal line of rat adrenal pheochromocytoma cells which respond to nerve growth factor. Proc Natl Acad Sci USA, 73 : 2424-2428, 1976.

11) Meldolesi J, Huttner WB, Tsien RY, et al: Free cytoplasmic $\mathrm{Ca}^{2+}$ and neurotransmitter release; Studies on PC12 cells and synaptosomes exposed to $\alpha$-latrotoxin. Proc Natl Acad Sci USA, $81: 620-624,1984$.

12）御子柴克彦, 宮本英七：カルシゥムシグナリングと細胞機 能. 細胞工学, 16:10-93, 1997.

13) Fu T, Sugimoto $Y$, Oki T, et al: Calcium oscillation associated with reduced protein kinase $\mathrm{C}$ activities in ras-transformed NIH3T3 cells. FEBS Letters, 281 : 263-266, 1991.

14）土肥宏樹：ヒト歯肉上皮細胞に対する低出カレーザーの作用 機序. 奥羽大歯学誌, 28:105-117, 2001.

15) Gourgouliatos ZF, Welch AJ, Diller KR, et al: Laser-irradiation-induced relaxation of blood vessels in vivo. Lasers Surg Med, 10 : 524-532, 1990.

16) Honmura A, Yanase M, Obata J, et al: Therapeutic effect of Ga-Al-As diode laser irradiation on experimentally induced inflammation in rats. Lasers Surg Med, 12 : 441-449, 1992.

17）山本博之, 尾崎昌宣, 井口賀之：ラットにおける経穴レー ザー照射の鎮痛効果. ペインクリニック， 8：43-48, 1987. 